$\underline{\text { Research Article }}$

\title{
The Effect of Extra Virgin Olive Oil (EVOO) on Fetal Birth Weight in Preeclampsia Rat Model
}

\author{
Pengaruh Extra Virgin Olive Oil (EVOO) terhadap Berat Badan Janin pada Tikus Model \\ Preeklamsia
}

\author{
Yulia Silvani, Afniari Maharani, Agnestia Naning, Dian Lovita \\ Department of Midwifery Faculty of Medicine Universitas Brawijaya Malang
}

\begin{abstract}
Preeclampsia, as one of the most common pregnancy-specific diseases, causes high maternal-fetal morbidity and mortality in almost every country. Placental vascular abnormalities in preeclamptic women can cause chronic hypoxia and impaired fetal nutrition, so fetal growth retardation often occurs. EVOO has strong antioxidant effect is assumed to prevent nutritional disorders in the fetus. This study aimed to determine the effect of EVOO on fetal birth weight in a preeclampsia rat model. This research was laboratory research conducted in vivo with a Post Test Only Control Group design which consisted of five groups; negative control group, positive control group (pre-eclampsia rat model), dose 1, 2, and 3 groups that were preeclampsia rats given EVOO in 3 different doses $10.5 \mathrm{~mL} /$ day, $1 \mathrm{~mL} /$ day and $2 \mathrm{~mL} /$ day respectively). Blood pressure and proteinuria measurements were carried out at the 12, 15 and 19day of pregnancy. After sacrificed, fetal weight was measured immediately using analytical balance. The result of this study showed that there was a significant reduction of fetal weight between negative control and positive control group ( $p=0.020)$, meanwhile no significant differences among positive control, dose 1 and dose 2 group $(p=0.90$ and $p=0.142)$ but statistically significant to dose 3 group ( $p=0.005)$. EVOO administration increases fetal weight in doses group by its AA and DHA in Long-Chain Poly Unsaturated Fatty Acids (LCPUFA) within. The optimal dose of EVOO to increase fetal weight is $2 \mathrm{~mL} /$ day.
\end{abstract}

Keywords: Extra virgin olive oil, fetal birth weight, preeclampsia

\section{ABSTRAK}

Preeklampsia, sebagai salah satu penyakit spesifik kehamilan yang paling umum, menyebabkan morbiditas dan mortalitas ibu-janin yang tinggi di hampir setiap negara. Kelainan vaskular plasenta pada wanita preeklampsia dapat menyebabkan hipoksia kronis dan gangguan nutrisi janin, sehingga sering terjadi retardasi pertumbuhan janin. EVOO memiliki antioksidan kuat, dan efek antiinflamasi diasumsikan untuk mencegah gangguan gizi pada janin. Penelitian ini bertujuan untuk mengetahui pengaruh EVOO terhadap berat lahir janin dalam model tikus preeklampsia. Penelitian ini adalah penelitian laboratorium yang dilakukan secara in vivo dengan desain penelitian Post Test Only Control Group yang terdiri dari lima kelompok; kelompok kontrol negatif, kelompok kontrol positif (model tikus pre-eklampsia), dosis 1, 2, dan 3 yang merupakan kelompok perlakuan yang diberi EVOO dalam 3 dosis berbeda (0,5 mL/day, $1 \mathrm{~mL} /$ day, dan $2 \mathrm{~mL} /$ day). Pengukuran tekanan darah dan proteinuria dilakukan pada hari ke 12, 15, dan 19. Setelah dibedah, berat janin diukur segera dengan menggunakan timbangan analitik. Hasil penelitian ini menunjukkan bahwa ada penurunan berat janin yang signifikan antara kontrol negatif dan kelompok kontrol positif $(p=0,020)$, sedangkan tidak ada perbedaan yang signifikan antara kelompok kontrol positif, dosis 1 dan dosis 2 ( $p=0,90$ dan $p=0,142$ ) tetapi signifikan secara statistik antara kelompok kontrol positif dengan kelompok dosis $3(p=0,005)$. Pemberian EVOO meningkatkan berat janin dalam kelompok dosis melalui AA dan DHA dalam asam lemak tak jenuh rantai panjang (long-chain polyunsaturated Fatty Acids). Dosis optimal EVOO untuk meningkatkan berat janin adalah dosis $2 \mathrm{~mL} /$ hari.

Kata Kunci: Berat badan janin, extra virgin olive oil, preeklamsia

Correspondence: Yulia Silvani. Department of Midwifery Faculty of Medicine Universitas Brawijaya Malang, Jl. Veteran Malang Tel. 085649031785Email:yhe.silvani@ub.ac.id

DOI: http://dx.doi.org/10.21776/ub.jkb.2020.031.01.3 


\section{INTRODUCTION}

Preeclampsia is one of the most common pregnancyspecific diseases, characterized by hypertension and proteinuria in pregnancies over 20 weeks, and is a cause of high maternal and fetal morbidity and mortality in almost every country (1). The incidence of preeclampsia varies between $2 \%$ to $10 \%$ of pregnancies worldwide. The World Health Organization estimates the incidence of preeclampsia to be seven times higher in developing countries ( $2.8 \%$ of live births) than in developed countries $0.4 \%$ (2). Preeclampsia is caused by many factors, including immunological, epigenetic, genetic, biochemical, environmental, and inflammatory factors as a basis for preeclampsia (3). There have been many in-depth studies related to the causes and pathogenesis of preeclampsia, but the exact cause is still unknown. Placental abnormalities and endothelial dysfunction have been proven by many researchers as the underlying cause of preeclampsia. The causes of endothelial dysfunction are also unclear, and many hypotheses are proposed to explain this (4).

Low birth weight and preeclampsia are pregnancy and child birth that have a negative impact on possible influence on future health status (5). Preeclampsia is associated with a high number of cases of small babies during pregnancy and perinatal deaths worldwide (6). In preeclampsia, there is a decrease in utero placental perfusion, hypovolemia, vasospasm, and damage to placental vascular endothelial cells (7). Uteroplacental ischemia results in hypoxia due to reduced blood flow at the placental implant site, and results in the release of free radicals. Oxidative stress can cause AT1-AA to induce activation of NADPH in endothelin 1 (ET-1) so that it can increase reactive oxygen species (ROS). The excessive amount of ROS causes an increase in p38 MAPK, which will reduce catalytic activity resulting in abnormal placentation. Trophoblast invasion failure and spiral artery remodeling result in hard and rigid arteries making it difficult to not even be able to vasodilate, this causes the blood supply to the placenta decreases resulting in hypoxia or placental ischemia $(8,9)$.

Placental vascular abnormalities in preeclamptic women can cause chronic hypoxia or uteroplacental ischemia and impaired fetal nutrition so that fetal growth retardation often occurs that can end in low birth weight (LBW) (10). Antioxidants are chemically interpreted as electron donor compounds. The work of antioxidants is through a chain reaction breaker mechanism. Antioxidants that are found in nature have been studied for various diseases (11). Antioxidant activity as a free radical scavenger, a reducing agent, and reducing the formation of singlet oxygen and electron donors are some of the biological effects of phenolic compounds (12). The content of phenolic compounds from extra virgin olive oil (EVOO) is very effective in counteracting free radicals (13). According to Calabriso et al., extra virgin olive oil (EVOO) is an external natural ingredient that has anti-antioxidant properties as well as ROS neutralizers (14).

Based on the background, it is assumed that in preeclampsia an increase in free radicals triggers oxidative stress, thus causing excessive apoptosis of trophoblast cells and endothelial dysfunction. Hypoxia as a result of placental endothelial cell damage can cause nutritional disturbances in the fetus and result in low birth weight. Extra virgin olive oil (EVOO) as a powerful antioxidant is assumed to prevent complication of preeclampsia by binding to existing oxidants, thereby reducing free radicals and preventing nutritional disorders in the fetus. To prove this assumption, a study will be conducted on the effect of extra virgin olive oil (EVOO) on birth weight in a preeclampsia rat model. Researchers used Rattus norvegicus experimental animals because they are able to adapt in laboratory environment well, classified as benign, easy to maintain, and their metabolic functions are similar to humans, so it is expected to be used as a comparison of preeclampsia in humans.

\section{METHOD}

\section{Animal Model}

This research was laboratory research conducted in vivo with a Post Test Only Control Group research design. The population in this study was pregnant Wistar strain rats. There were four replications for each group (15). The negative control group was normal pregnant rats; the positive control was pregnant pre-eclampsia rats (preeclampsia rat model); and the treatment group 1, 2, and 3 were preeclampsia rat given three different doses $(0,5$ $\mathrm{mL} /$ day, $1 \mathrm{~mL} /$ day and $2 \mathrm{~mL}$ /day) of Extra Virgin Olive Oil (EVOO), respectively (16). The morning after mating, each animal was examined for the presence of a vaginal plug. The presence of a vaginal plug was assumed to be the day 1 of pregnancy. The research was carried out in the Laboratory of Bioscience Universitas Brawijaya, Laboratory of Physiology and Laboratory of Biomolecular Biochemistry, Faculty of Medicine Universitas Brawijaya Malang.

\section{Preeclampsia Induction and EVOO Administration}

The induction material for preeclampsia was using NOS inhibitors, L-NAME (C7H15N5O4 HCl) from Sigma-Aldrich (Merck KGaA, Darmstadt, Germany) (17). The L-Name dose given was $125 \mathrm{mg} / \mathrm{kg}$ BW starting from day 13 to day 18 intraperitoneally (18-19). While, the EVOO " $\mathrm{B}$ " was given per oral gavage feeding tube from day 1 to day 18 of pregnancy.

\section{Clinical Examination}

Clinical examination was carried out by using non-invasive blood pressure measurement $\left(\mathrm{CODA}^{\circledR}\right.$, Kent Scientific Corporation) available at the Laboratory of Physiology, Faculty of Medicine Universitas Brawijaya, and proteinurin with dipstick examination (URISCAN ${ }^{\circledR} 3 \mathrm{GPH}$ strips). Blood pressure and urine protein measurements were carried out at the 12,16, and 19 day of pregnancy. The presence of vaginal plug in the morning after mating was determined as day 1 of pregnancy. Fetal weight was measured immediately using analytical balance after the rats were sacrificed.

\section{Data Analysis}

The data analysis was conducted using SPSS 25.0. The normality test was done using Shapirowilk, and test homogeneity of variance was using lavene statistic. Independent t-test was used to compare the negative and the positive control groups, while one-way ANOVA was used to describe the differences of each group.

\section{RESULTS}

Blood Pressure Examination

The success of making preeclampsia rat model could be 
seen from the increasing systolic blood pressure (shown in Figure 1) and the increasing diastolic blood pressure (shown in Figure 2) after being given L-NAME (N ( $\omega)$-nitroL-arginine methyl ester). Blood pressure checkswere performed on day 12 of pregnancy, day 15 of pregnancy (after L-NAME administration), and day 19 of pregnancy (before surgery).

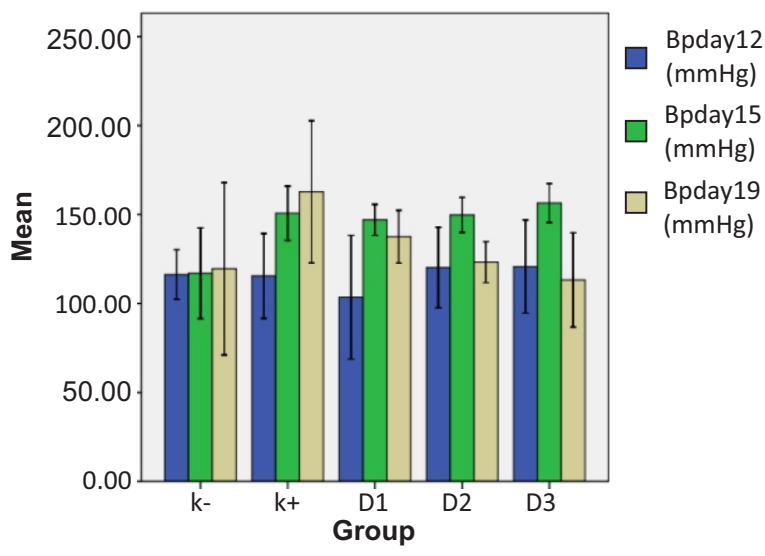

Figure 1. Blood Pressure (Systolic)

Note: Negative control (K-) normal pregnant rat, positive control $(\mathrm{K}+)$ preeclampsia rat model without EVOO, preeclampsia rat model were given EVOO $0.5 \mathrm{~mL} /$ day dose 1 (D1), EVOO $1 \mathrm{~mL} /$ day dose 2 (D2), EVOO $2 \mathrm{~mL} /$ day dose 3 (D3).

In the negative control group, there was no difference in systolic blood pressure between groups (Figure 1). In the positive control group there was an increase in systolic blood pressure from day 12 to day 15 and day 19 of pregnancy; in D1 group, there was an increase in systolic blood pressure on the day of systole from day 12 to day 15 of pregnancy then decreased slightly in day 19 of pregnancy; in D2 group, there was an increase in systolic blood pressure on the day of systole from day 12 to day 15 of pregnancy, then in day 19 of pregnancy decreased as same as day 12 of pregnancy; in group 3, there was an increase in systolic blood pressure from day 12 to day 15 of pregnancy, in day 19 of pregnancy decreased more than day 12 of pregnancy.

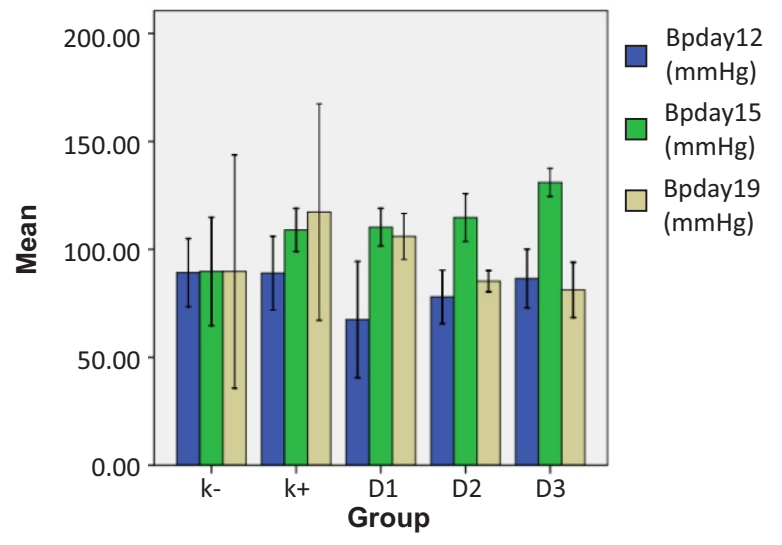

Figure 2. Blood Pressure (Diastolic)

Note: Negative control (K-) normal pregnant rat, positive control $(\mathrm{K}+)$ preeclampsia rat model without EVOO, preeclampsia rat model were given EVOO $0.5 \mathrm{~mL} /$ day dose 1 (D1), EVOO $1 \mathrm{~mL} /$ day dose 2 (D2), EVOO $2 \mathrm{~mL} /$ day dose 3 (D3).
In the negative control group, there was no difference in diastolic blood pressure between groups (Figure 2). In the positive control group, there was an increase in diastolic blood pressure from 12 to day 15 and day 19 of pregnancy; in D1 group, there was an increase in diastolic blood pressure from day 12 to day 15 of pregnancy then decreased slightly in day 19 of pregnancy; in D2 group, there was an increase in diastolic blood pressure from day 12 to day 15 of pregnancy, then in day 19 of pregnancy seem decreased; in D3 group, there was an increase in diastolic blood pressure from day 12 to day 15 of pregnancy then decreased more than day 12 of pregnancy.

Measurement of Fetal Weight On day 19, surgery and measurement of fetuses' weigh were carried out in each group (Table 1). From the results of the Shapiro Wilk Normality Test, the obtained showed that all data for each group were normal ( $p=0.982 ; p=0.066 ; p=0.161 ; p=0.303$; $p=0.063)$. The results of the homogeneity of variances test with the Levene statistical results showed that all data were homogeneous $(p=0.064)$. The independent t-test results showed that there were significant differences between the negative control group and the positive control group $(p=0.020)$. This showed that there was a significant reduction in fetal weight in preeclampsia when compared to normal rats. While, the Anova Test also showed significant results $(p=0.001)$. The post hoc test using LSD showed that there was no significant difference between the positive control group and dose 1 and 2 groups ( $p=0.90$ and $p=0.142$ ) but significantly different with dose 3 group ( $p=0.005)$. Statistically, this means that EVOO significantly increasesthe fetal weight from positive control in dose $2 \mathrm{~mL} /$ day.

Table 1. Fetuses' weight

\begin{tabular}{ccccccc}
\hline & $\begin{array}{c}\text { Rat 1 } \\
\mathbf{( g )}\end{array}$ & $\begin{array}{c}\text { Rat 2 } \\
\mathbf{( g )}\end{array}$ & $\begin{array}{c}\text { Rat 3 } \\
\mathbf{( g )}\end{array}$ & $\begin{array}{c}\text { Rat 4 } \\
\mathbf{( g )}\end{array}$ & $\begin{array}{c}\text { Mean } \\
(\mathbf{g} \pm \text { SD) }\end{array}$ & $\begin{array}{c}\overline{\mathbf{x}} \mathbf{\Sigma} \\
\text { fetuses }\end{array}$ \\
\hline K- & 2.83 & 1.44 & 2.42 & 3.85 & $2.64 \pm 0.99$ & 7.75 \\
K+ & 0.82 & 0.94 & 1.42 & 0.81 & $0.99 \pm 0.29$ & 8 \\
D1 & 1.36 & 1.24 & 1.32 & 1.36 & $1.32 \pm 0.057$ & 5.75 \\
D2 & 2.24 & 2.33 & 1.44 & 1.82 & $1.96 \pm 0.19$ & 9.25 \\
D3 & 3.2 & 2.33 & 2.37 & 2.88 & $2.69 \pm 0.40$ & 8.5 \\
\hline
\end{tabular}

Note: the average of fetal weight was obtained from 4 samples in each group; mean of fetuses weigh from each groupshows that positive control group had the lowest mean; the average of total fetuses each group. Fetuses weight is the average of fetuses in each sample with different amounts.

\section{DISCUSSION}

Increase Systolic and Diastolic Pressure as Marker of Preeclampsia

Preeclampsia rat model was made by intraperitoneal injection of $125 \mathrm{mg} / \mathrm{kg}$ BW L-NAME (19). L-NAME injection in pregnant rat inhibits Nitric Oxide (NO) synthase that produce from converting L-arginine to NO by NOS (nitric oxide synthase). Lack of NO as vasodilatator causes blood vessels of preeclampsia in vasoconstriction condition. Vascular vasoconstriction triggers increasing systolic and diastolic pressure in preeclampsia. In this study, systolic and diastolic blood pressure increased, day 12 to 15 of pregnancy both systolic and diastolic in preeclampsia rat model (Figure 1 and 2), in accordance with previous studies (19-21). 
Meanwhile, based on the result of this study, after EVOO treatment, systolic and diastolic blood pressures seem to decrease (day 15 to 19 of pregnancy both systolic and diastolic in the preeclampsia rat model, as seen in Figure 1 and 2). Hypertension is related to poor endothelial function caused by vascular oxidative stress and inflammation. Olive oil polyphenol decreases blood pressure in hypertension and improves endothelial function by a mechanism that reduces serum Asymmetric Dimethyl Arginine (ADMA), ox-LDL, plasma C Reactive Protein (CRP) concentration (22).

ADMA as inhibitor molecule of NO synthase to produce $\mathrm{NO}$, in which hypertension blood vessel in vasoconstriction condition is widely known as consequence lack of NO (23). In oxidative stress, free radical disrupt lipid forming ox-LDL and lead to increase ADMA. Ox-LDL upregulates Protein Arginine Methyltransferases (PRMTs), enzyme catalyzer arginine methylation to form ADMA (24). Anthocyanin as polyphenol antioxidant in EVOO has double bonds and hydroxyl groups that bind free radicals and inhibit LDL oxidation at the initiation and propagation stage, so radical compounds do not have enough energy to react with other lipid molecules (25).

Ox-LDL activates the renin-angiotensin system and angiotensin II to increase blood pressure (26). Olive oil polyphenol reduces ox-LDL because antioxidant compound of olive oil polyphenol, mainly hydroxytyrosol, is responsible for lowering lipoprotein oxidation and disrupting chain oxidation reaction (27). CPR is inducing endothelial dysfunction by declining NO synthase mRNA stability and uncoupling (28). Anti-inflammatory effect of olive oil polyphenol through several molecular pathways including arachidonic acid pathway and nuclear factor-Kb results in decreasing CRP $(29,30)$. Therefore, olive oil polyphenol decreases blood pressure through increasing NO bioavailability due to decreasing ADMA, ox-LDL, and CRP concentration (31).

\section{Fetal Weight in Preeclampsia Rat Model}

In our study, the mean of fetal weight in the positive control group was lower than the negative control group (Table 1). In preeclampsia, there was a disruption of uteroplacental perfusion which caused placenta tend to be in a state of lack oxygen and lead to placental ischemia. In condition of placental ischemia, maternal-fetal exchange of oxygen and nutrients reduce so that affect fetal growth and development (1,32). Disruption of uteroplacental perfusion in preeclampsia proved by morphological change in placenta which showed lower placental weight compared to normal pregnancy $(33,34)$. Placental ischemia affects fetal growth by limiting oxygen and negatively influences placental glucose transport as a primary source of energy for the fetus (35). Oxygen, glucose, amino acids, and fatty acids are the main nutrients required for appropriate fetal development and growth. Thus, placental ischemia due to disruption of uteroplacental perfusion affects nutrient transport lead to lower birth weight (36).

\section{Effect of EVOO in Fetal Birth Weight}

This study showed that EVOO can increase fetal weight compared to the positive control group. This is in accordance with the results of previous studies that EVOO administration can increase fetal weight compared with controls (37). The bioactive component found in EVOO includes monounsaturated fatty acids and polyunsaturated fatty acids, tocopherols, and polyphenols (bio-phenols) (38). The long-chain polyunsaturated Fatty Acids (LCPUFA) such as arachidonic acid (AA), timnodonic acid (EPA), arachidonic acid (ARA) and cervonic acid (DHA) are involved in key biological processes, including inflammatory responses, gene expression, and cellular fluidity $(39,40)$. DHA and ARA are very important during pregnancy for fetuses because they form structural constituents of membrane lipids lead to increase fetal weight (40). Former Cross-Sectional human studies have extensively demonstrated lower LCPUFA levels in pregnancy complications like preeclampsia $(41,42)$. Therefore, this study suggeststhatin preeclampsia EVOO consumption will improve the fetal birth weight.

The use of EVOO is often linked to the Mediterranean diet (MD), whose composition mainly consists of fruits, vegetables, and olive oil (43). Some studies showed that low adherence to the Mediterranean diet (MD) in early pregnancy was significantly associated with a decrease in fetal size, placenta, and birth weight $(44,45)$. There is a lot of evidence regarding the risk of cardiovascular disease and other chronic diseases. The benefits of MD have also been associated with a reduction in oxidative stress through its phenolic components (46-48).

Our study, where early EVOO (early pregnancy) administration was given in late onset preeclampsia which is expected to lead to increased birth weight. This results is also in line with a study that stated (49) there is strong evidence from various disciplines that mention pregnancy humans consist of two opposite periods. During the first trimester, there is little maternal blood flow to the placenta and low oxygen pressure to feto-placenta, but the uterine gland can provide a lot of nutrient supply. Whereas at the beginning of the second trimester, maternal circulation in the intervillous space gets better, oxygen pressure increases, and hemotropic nutrition becomes dominant.

We conclude that preeclampsia in rat model causes lower birth weight, meanwhile administration of EVOO decreases blood pressure and increase fetal weight.

\section{ACKNOWLEDGEMENT}

We would like to express the gratitude to our supervisor $d r$. I Wayan Arsana Sp.OG (K), Dr. dr. Retty Ratnawati, dr. Hidayat Sujuti, Sp.M, Ph.D, and Dr. Tri Yudani Mardining Raras,.rer nat., M.App.Sc. Special thanks to laboratory staffs and technicians in Bioscience Laboratory and Faculty of Medicine Universitas Brawijaya.

\section{REFERENCES}

1. Hod T, Cerdeira AS, and Karumanchi SA. Molecular Mechanisms of Preeclampsia. Cold Spring Harbor Perspectives in Medicine. 2015; 5(10): 1-20.

2. Osungbade KO and Ige OK. Public Health Perspectives

of Preeclampsia in Developing Countries: Implication for Health System Strengthening. Journal of pregnancy. 2011; 2011: 1-6.

3. Chelbi ST and Vaiman D. Genetic and Epigenetic Factors Contribute to the Onset of Preeclampsia. 
2008; 282(1-2): 120-129.

4. Stepan H, Faber R, Dornhöfer N, Huppertz B, Robitzki $\mathrm{A}$, and Walther T. New Insights Into the Biology of Preeclampsia. 2006; 74(5): 772-776.

5. Sherf Y, Sheiner E, Shoham VI, Sergienko R, Klein J, and Bilenko N. Like Mother Like Daughter: Low Birth Weight and Preeclampsia Tend to Reoccur at the Next Generation. The Journal of Maternal-Fetal \& Neonatal Medicine. 2019; 32(9): 1478-1484.

6. Luealon $\mathrm{P}$ and Phupong $\mathrm{V}$ Risk Factors of Preeclampsia in Thai Women. Journal of the Medical Association of Thailand. 2010; 93(6): 661-666.

7. Sarwono P. Ilmu Kebidanan. Jakarta: Yayasan Bina Pustaka; 2010.

8. Cindrova-davies T. The Therapeutic Potential of Antioxidants, ER Chaperones, NO And H2S Donors, and Statins for Treatment of Preeclampsia. Frontiers in Pharmacology. 2014; 5: 1-14.

9. Gilbert JS, Ryan MJ, LaMarca BB, et al. Pathophysiology of Hypertension During Preeclampsia Linking Placental Ischemia with Endothelial Dysfunction. 2008; 294(2): 541-550.

10. Lukito JS and Dewi LP. Gambaran Histopatologi Arteri Spiralis Alas Plasenta pada Preeklampsia/Eklampsia dan Kehamilan Normotensif. Majalah Kedokteran Nusantara. 2007; 40(3): 173-179.

11. Jeyabalan A and Caritis SN. Antioxidants and the Prevention of Preeclampsia - Unresolved Issues. The New England Journal of Medicine. 2006; 357(17): 1841-1843.

12. Karadeniz F, Burdurlu HS, Koca N, and Soyer Y. Antioxidant Activity of Selected Fruits and Vegetables Grown in Turkey. Turkish Journal of Agriculture and Forestry. 2005; 29(4): 297-303.

13. Keceli T and Gordon MH. The Antioxidant Activity and Stability of the Phenolic Fraction of Green Olives and Extra Virgin Olive Oil. Journal of the Science of Food and Agriculture. 2001; 81(14): 1391-1396.

14. Calabriso N, Scoditti E, Massaro M, et al. Multiple Anti- Inflammatory and Anti- Atherosclerotic Properties of Red Wine Polyphenolic Extracts: Differential Role of Hydroxycinnamic Acids, Flavonols and Stilbenes on Endothelial Inflammatory Gene Expression. European Journal of Nutrition. 2016; 55(2): 477-489.

15. Schwager SJ, Mutschler MA, Federer WT, and Scully BT. The Effect of Linkage on Sample Size Determination for Multiple Trait Selection. Theoretical and Applied Genetics. 1993; 86(8): $964-$ 974.

16. Irianti E, Ilyas S, Rosidah, and Hutahaean S. Hsp70 Expression Profile in Preeclampsia Model of Pregnant Rat (Rattus Norvegicus) after Giving the EVOO. IOP Conference Series: Materials Science and Engineering. 2017; 180: 1-6.

17. Amaral TAS, Ognibene DT, Carvalho LCRM, et al. Differential Responses Of Mesenteric Arterial Bed To Vasoactive Substances In L-NAME-Induced Preeclampsia: Role of Oxidative Stress And
Endothelial Dysfunction. Clinical and Experimental Hypertension. 2018; 40(2): 126-135.

18. Shu W, Li H, Gong H, et al. Evaluation of Blood Vessel Injury, Oxidative Stress and Circulating Inflammatory Factors in an L-Name-Induced Preeclampsia-Like Rat Model. Experimental and Therapeutic Medicine. 2018; 16(2): 585-594.

19. Zhu H, Zhu W, Hu R, Wang H, Ma D, and LiX. The Effect of Pre-Eclampsia-Like Syndrome Induced by L-NAME on Learning and Memory and Hippocampal Glucocorticoid Receptor Expression: A Rat Model. Hypertension in Pregnancy. 2017; 36(1): 36-43.

20. Droge W. Free Radicals in the Physiological Control of Cell Funtion. Physiological Reviews. 2002; 82(1): 4795.

21. Suzuki H, Ohkuchi A, Shirasuna K, et al. Animal Models of Preeclampsia: Insight Into Possible Biomarker Candidates for Predicting Preeclampsia. Medical Journal of Obstetrics and Gynecology. 2014; 2(2): 1-12.

22. Keita H, Ramírez-San Juan E, Paniagua-Castro N, Garduño-Siciliano L, and Quevedo L. The Long-Term Ingestion of a Diet High in Extra Virgin Olive Oil Produces Obesity and Insulin Resistance but Protects Endothelial Function in Rats: A Preliminary Study. Diabetology and Metabolic Syndrome. 2013; 5(1): 1-10.

23. Blackwell S. The Biochemistry, Measurement and Current Clinical Significance of Asymmetric Dimethylarginine of Asymmetric Dimethylarginine. Annals of Clinical Biochemistry. 2010; 47(1): 17-28.

24. Kim DI, Park MJ, Choi JH, et al. PRMT1 and PRMT4 Regulate Oxidative Stress-Induced Retinal Pigment Epithelial Cell Damage In SIRT1-Dependent And SIRT1-Independent Manners. Oxidative Medicine and Cellular Longevity. 2015; 2015: 1-9.

25. Fathoni ZU, Indra R, and Supranowo. Ekstrak Rosela Menurunkan Perlemakan dan Ekspresi ADMA Hepar Akibat Diet Aterogenik pada Tikus. Jurnal Kedokteran Brawijaya. 2014; 28(1): 6-10.

26. Yamamoto K, Kakino A, Takeshita $\mathrm{H}$, et al. Oxidized LDL (OxLDL) Activates the Angiotensin I/ Type 1 Receptor by Binding to the Lectin-Like OxLDL Receptor. Federation of American Societies for Experimental Biology Journal. 2015; 29(8): 33423356.

27. Fraga CG, Galleano M, Verstraeten S V, and Oteiza PI. Basic Biochemical Mechanisms Behind the Health Benefits of Polyphenols. Molecular Aspects of Medicine. 2010; 31(6): 435-345.

28. Devaraj S, Siegel D, and Jialal I. Statin Therapy in Metabolic Syndrome and Hypertension PostJUPITER: What is the Value of CRP? Current Atherosclerosis Reports. 2011; 13(1): 31-42.

29. Hussain T, Tan B, Yin Y, Blachier F, Tossou MCB, and Rahu N. Oxidative Stress and Inflammation: What Polyphenols Can Do For Us? Oxidative Medicine and Cellular Longevity. 2016; 2016: 1-9.

30. de Souza PAL, Marcadenti A, and Portal VE. Effects of Olive Oil Phenolic Compounds on Inflammation in the 
Prevention and Treatment of Coronary Artery Disease. Nutrients. 2017; 9(10): 1-22.

31. Moreno-luna R, Muñoz-hernandez R, Miranda ML, et al. Olive Oil Polyphenols Decrease Blood Pressure and Improve Endothelial Function in Young Women with Mild Hypertension. America Journal of Hypertension. 2012; 25(12): 1299-1304.

32. Cerdeira AS and Karumanchi SA. Angiogenic Factors in Preeclampsia and Related Disorders. Cold Spring Harbor Perspectives in Medicine. 2012; 2(11): 1-17.

33. Milosevic-Stevanovic J, Krstic M, Radovic-Janosevic D, Stefanovic M, Antic V, and Djordjevic I. Hypertension in Pregnancy Preeclampsia With and Without Intrauterine Growth Restriction - Two Pathogenetically Different Entities? Hypertension in Pregnancy. 2016; 35(4): 1-10.

34. Freitas R De, Vieira A, Medeiros LA, Diniz D, and Id NP. The Role of the Erythrocyte in the Outcome of Pregnancy with Preeclampsia. PLoS One. 2019; 14(3): 1-17.

35. von Versen-Hoeynck FM and Powers RW. Maternalfetal Metabolism in Normal Pregnancy and Preeclampsia. Frontiers in Bioscience: A Journal and Virtual Library. 2007; 12: 2457-2470.

36. Winterhager E and Gellhaus A. Transplacental Nutrient Transport Mechanisms of Intrauterine Growth Restriction in Rodent Models and Humans. Frontiers in Physiology. 2017; 8: 1-13.

37. Salem A. Effect of Feeding on Olive Oil and Thyme on Pregnancy and Lactation Periods. International Journal of Nutrition and Food Sciences. 2015; 4(1): 19-28.

38. Nocella C, Cammisotto V, Fianchini L, et al. Extra Virgin Olive Oil and Cardiovascular Diseases: Benefits for Human Health. Endocrine, Metabolic \& Immune Disorders - Drug Targets. 2018; 18(1): 4-13.

39. Steer CD, Hibbeln JR, Golding J, and Smith GD. Polyunsaturated Fatty Acid Levels in Blood During Pregnancy, at Birth and at 7 Years: Their Associations with Two Common FADS2 Polymorphisms. Human Molecular Genetics. 2012; 21(7): 1504-1512.
40. Larqué E, Gil-Sánchez A, Prieto-Sánchez MT, and Koletzko B. Omega 3 Fatty Acids, Gestation and Pregnancy Outcomes. The British Journal of Nutrition. 2012; 107: 77-84.

41. Kulkarni A V, Mehendale SS, Yadav HR, and Joshi SR. Reduced Placental Docosahexaenoic Acid Levels Associated with Increased Levels of SFlt-1 in Preeclampsia. Prostaglandins Leukotrienes and Essential Fatty Acids. 2011; 84(1-2): 51-55.

42. Dangat KD, Mehendale S, Yadav HR, et al. Long-Chain Polyunsaturated Fatty Acid Composition of Breast Milk in Pre-Eclamptic Mothers. Neonatology. 2010; 97(3): 190-194.

43. Sofi F, Cesari F, Abbate R, Gensini GF, and Casini A. Adherence to Mediterranean Diet and Health Status: Meta Analysis. 2008; 337(7671): 1-7.

44. Santangelo C, Vari R, Scazzocchio B, and Masella R. Management of Reproduction and Pregnancy Complications in Maternal Obesity: Which Role for Dietary Polyphenols? BioFactors. 2013; 40(1): 79102.

45. Timmermans $\mathrm{S}$, Steegers-Theunissen RP, Vujkovic M, et al. The Mediterranean Diet and Fetal Size Parameters: The Generation R Study. The British Journal of Nutrition. 2012; 108(8): 1399-1409.

46. Martinez-Gonzalez MA, Bes-Rastrollo $M$, SerraMajem L, Lairon D, Estruch R, and Trichopoulou A. Mediterranean Food Pattern and the Primary Prevention of Chronic Disease: Recent Developments. Nutrition Reviews. 2009; 67(1): 111-116.

47. Bonaccio M, lacoviello L, Gaetano G De, and MoliSani Investigators. The Mediterranean Diet: The Reasons for a Success. Thrombosis Research. 2012; 129(3): 401-404.

48. Bogani P, Galli C, Villa M, and Visioli F. Postprandial Anti-Inflammatory and Antioxidant Effects of Extra Virgin Olive Oil. 2007; 190(1): 181-186.

49. Burton GJ and Jaunaiux E. Maternal Vascularisation Of The Human Placenta: Does The Embryo Develop In A Hypoxic Environment? Gynécologie Obstétrique \& Fertilité. 2001; 29(7-8): 503-508 